\title{
El largo periplo de un documento colonial: La Pintura de la Peregrinación de los culhuas-mexitin (El Mapa de Sigüienza) ${ }^{1}$
}

\author{
María Castañeda de la Paz \\ Universidad de Copenhague
}

El documento del que en estas páginas se habla es un importante manuscrito pictográfico del México antiguo elaborado durante la Colonia. Como otros muchos documentos de aquella época, pasó de mano en mano formando parte de las grandes colecciones de los personajes de más renombre del México colonial, moderno y contemporáneo. Finalmente, en 1904, fue rescatado por el entonces Museo Nacional de donde había sido sustraído, al tenerse noticias de que estaba a la venta en un bazar de antigüedades de la Ciudad de México. El objetivo del presente trabajo es dar a conocer las vicisitudes por las que pasaron muchos de los documentos con los que hoy trabajamos, así como los pasos a seguir en su búsqueda. Para esto hemos tomado como ejemplo La Pintura de la Peregrinación de los culhuas-mexitin.

Palabras Claves: México, códices, periodo colonial.

The document that will be discussed here is an important pictographical manuscript of Ancient Mexico made in the colonial period. As other documents of this time it passed from hand to hand forming part of the large collections of most renowned persons of colonial, modern, and present day Mexico. In 1904, after receiving notice that it was for sale in a Bazar of antiquities in Mexico City, it was finally rescued by the National Museum from which it had been taken. As such, the objective of the present contribution is to inform scholars of the vissicitudes of many documents with which we work today. The Pintura de la Peregrinación de los culhuas-mexitin has been taken as an example.

Keywords: Mexico, codex, colonial period.

\section{Introducción}

La historia de La Pintura de la Peregrinación de los culhuas-mexitin que aquí se tratará es una muestra de la suerte que corrieron numerosos documentos prehispánicos y coloniales mexicanos, hoy dispersos por distintas partes del mundo. Cuando inicié esta investigación nunca llegué a sospechar las vicisitudes por las que este manuscrito se vio obligado a

1 El título de La Pintura de la Peregrinación de los culhua-mexitin responde a una nomenclatura más en consonancia con el contenido del documento y su contexto cultural. Sin embargo, para no confundir a los lectores he conservado su antiguo nombre entre paréntesis. 
pasar y cómo, en 1904 y por fortuna del destino, pudo ser recuperado por el entonces Museo Nacional de México.

El documento en cuestión es un importante manuscrito pictográfico para el estudio de la historia mexica (figura 1). Se elaboró en la segunda mitad del siglo XVI o principios del XVII sobre papel de amate (54'5 $\times$ $77^{\prime} 5 \mathrm{cms}$.), y en él se narra la peregrinación de los aztecas-mexitin desde su salida de Aztlan-Teoculhuacan hasta la fundación de Tenochtitlan, centrando particularmente su atención en la estancia en Chapultepec. ${ }^{2}$ Hoy día, y después de un largo periplo, se custodia en la Bóveda de Códices de la Biblioteca Nacional de Antropología e Historia de la Ciudad de México, catalogado bajo la númeración $35-14 .^{3}$

En líneas generales podemos decir que todo este complejo recorrido histórico comienza cuando las circunstancias vividas en el corazón del valle mexicano provocaron que La Pintura de la Peregrinación, como otros muchos documentos, quedaran fueran de su contexto originario y comenzaran un largo camino hasta su destino actual. Aunque la idea generalmente aceptada es que formó parte del grupo de manuscritos del Archivo de Texcoco, celosamente guardado por los nobles de esta ciudad, no podemos hablar con certeza de ella hasta que entra a formar parte de la gran colección que alcanzó a reunir el erudito mexicano Carlos de Sigüenza y Góngora. Fue entonces cuando adquirió el nombre de Mapa de Sigüenza, denominación con la que hasta actualmente se le ha conocido. ${ }^{4}$ Tras la muerte de Sigüenza, el documento pasó de mano en mano, más como un objeto curioso, interesante, valioso y digno de colección, que como un ver-

2 Remito al lector interesado en el contenido histórico del manuscrito a Castañeda de la Paz, María: "La Pintura de la Peregrinación culhua-mexica (Mapa de Sigüenza). Nuevas aportaciones a su estudio", Relaciones. Estudios de Historia y Sociedad, México, 2001, vol. XXII, núm. 86, págs. 83-114.

3 Desde estas líneas deseo dar las gracias a todo el personal de dos instituciones relevantes para mi trabajo: la Biblioteca Nacional de Antropología e Historia en la Ciudad de México y la Biblioteca Nacional de París. De manera especial expreso mi agradecimiento al Dr. César Moheno y al Mto. Manuel Hermann — director general y director de documentación respectivamente — de la primera de estas instituciones, y a la Dra. Monique Cohen, directora de la Sala de Manuscritos Orientales en París, por todo el apoyo y facilidades que me brindaron para trabajar en dichas instituciones, siendo de gran importancia para mi trabajo el haber tenido acceso a los documentos originales solicitados que allí se guardan. Asimismo, toda mi gratitud a numerosos colegas y amigos con quienes compartí horas de discusión en torno al tema. En México, a Xavier Noguez, Sebastián van Doesburg Rafael Tena, y Carmen Aguilera. En Holanda, a Maarten Jansen, Michel Oudijk, Laura van Broeckhoven, Rosanna Woensdregt, Michael Swanton y Hans Roskamp.

4 Asimismo ha poseído los de Cuadro-jeroglífico de Sigüenza, Codex Sigüenza o Códice Ramírez, entre otros. Glass, John: Handbook of Middle American Indians, Texas, 1975, vol. 14, págs. 197-198. 


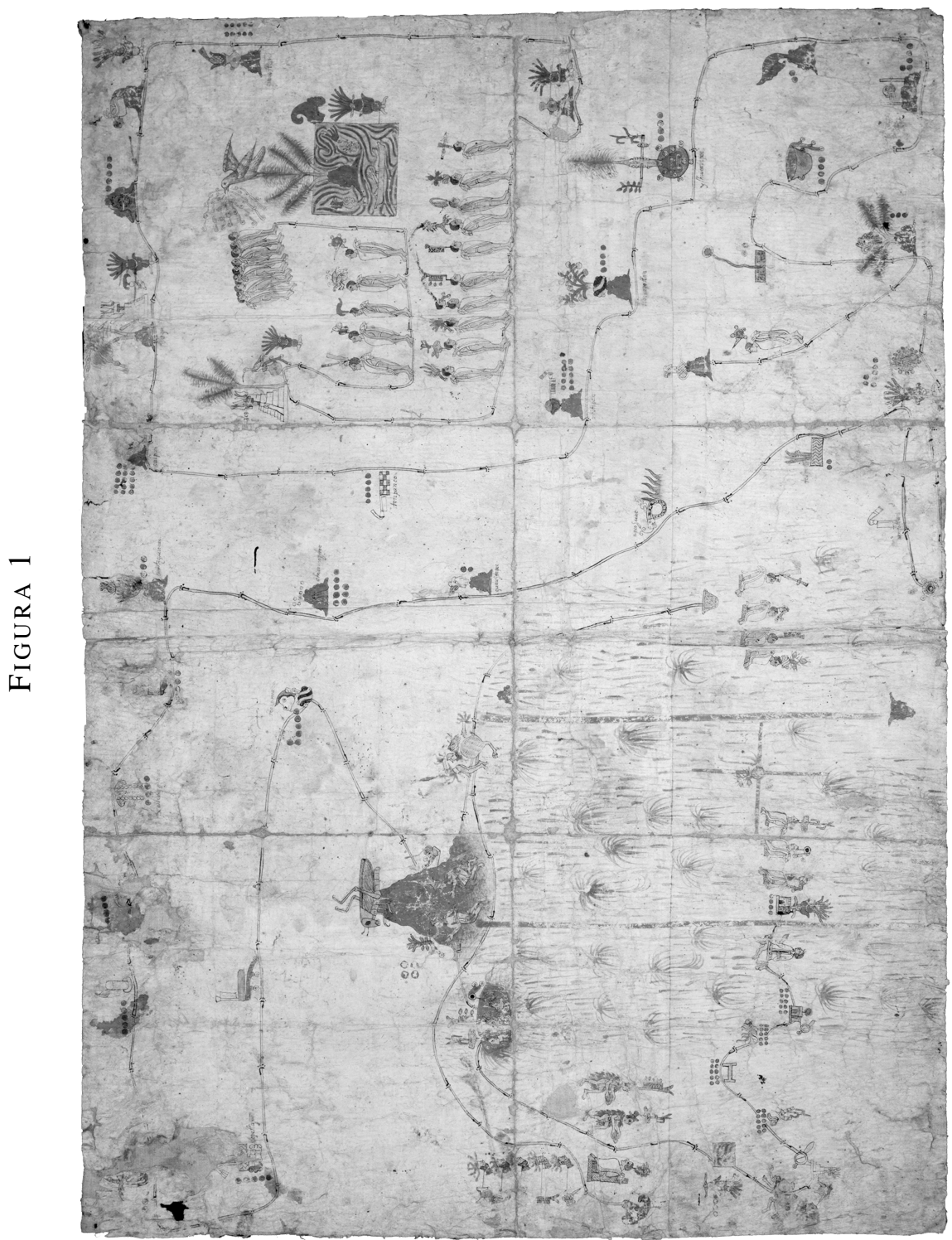


dadero documento histórico, que como tal tenía su propio valor, por no mencionar la suma importancia que debió poseer para el pueblo que hasta su momento lo conservó.

Mi deseo es aprovechar estas líneas para conducir al lector por todos los caminos a recorrer en la búsqueda de un manuscrito que, sin duda, estuvo en las estanterías de los personajes de más renombre en cada tiempo, compartiendo espacio con otros documentos no de menor importancia. Dedicaré un apartado a la historia del manuscrito, en el cual iremos viendo quiénes fueron sus propietarios y si éstos generaron alguna copia. Al tema del robo del Museo le he dedicado un punto aparte debido a lo insólito de la situación. Todos sabemos que fueron numerosos los documentos sustraídos de diversos lugares y de las más distintas maneras. Sin embargo, la falta de información y todo el secretismo que envolvía al caso creó en mí una enorme curiosidad, que pude satisfacer gracias al trabajo de hemeroteca, con sorprendentes resultados. El tercer punto se conecta con el primero y está dedicado a las diferentes copias que se hicieron de la Pintura a lo largo de los siglos, 12 en total, algunas de ellas en paradero desconocido. Un aspecto ciertamente interesante para observar las modificaciones y distorsiones que pueden generarse a partir de un original. Un último punto estará dedicado a las conclusiones.

\section{Historia del documento: sus propietarios}

Antes de entrar en materia quiero hacer hincapié en que el documento del que aquí se habla es un manuscrito colonial, basado en uno prehispánico hoy desconocido:

"La finalidad que tuvo el autor de tal pintura (copiada de un original hecho por los indios en los tiempos de su gentilidad), fue la de manifestar que su antiguiedad era la misma que la del diluvio [...]".

A pesar de todo y hasta la fecha, la historia de la Pintura ha sido bastante oscura. La razón son las constantes contradicciones y omisiones que existen entre los diferentes autores acerca de los propietarios que la han poseído. Efectivamente, en numerosas ocasiones el rastro se hace tan difí-

5 Gemelli Carreri, Giovanni Francesco: Viaje a la Nueva España, México, 1976, lib. I, cap.IV, pág. 25. 
cil que se ha considerado que la mejor forma de llegar a ella es dejando hablar a todos aquellos que, en distintas épocas, dijeron haber visto el manuscrito o tener información de él.

Para partir de un punto seguro, nadie duda que el documento estuvo en manos de Sigüenza y Góngora. Ahora bien, ¿de dónde lo obtuvo? La idea generalmente aceptada — pero no por ello del todo segura- es que lo recibiera junto con otros papeles de Juan de Alva Ixtlilxochitl, también conocido como Juan de Alva Cortés, noble indígena descendiente de la casa real de Texcoco. Su entroncamiento directo con el famoso historiador Fernando de Alva Ixtlilxochitl explica que conservara gran parte de los documentos del archivo de su ciudad, el cual a su muerte, hacia 1682, legó a Sigüenza:

"[...] como eruditamente va señalando don Carlos de Sigüenza y Góngora, catedrático propietario y profesor de matemáticas de la Universidad de México, en su Cyclografía, en la cual se sirve de pasajes de las sagradas escrituras, de tradiciones de los indios, de pinturas y de jeroglíficos muy singulares que habían sido conservados por don Juan de Alba, señor del cacicazgo de San Juan de Teotihuacan. Éste las había heredado de sus mayores que habían sido reyes de Texcoco, de quienes descendía por línea directa, y las dejó en manos de don Carlos, su albacea testamentario".

No obstante, el historiador mexicano Alfredo Chavero, siguiendo a su maestro, el director y luego conservador del Museo Nacional de México, José Fernando Ramírez, defendía la idea de que Sigüenza obtuvo la Pintura del padre Duarte, quien procedente de las Filipinas llegó a México, donde residió entre 1666 y 1680. Para este argumento reproducía las palabras de Duarte acerca de los manuscritos que poseyó, entre ellos el llamado manuscrito de Filipinas:

"Quiero escribir aquí una historia pintada por figuras al modo de los Indios, la cual tuve en México más de catorce años, sin entenderla del todo, hasta que llegué á leer

6 Ibídem, lib.I, cap.V, págs. 52, 55. Nos dice O’Gorman que el cacique era amigo de Sigüenza, además de su representante en varios casos judiciales, entre ellos un largo pleito por el cacicazgo que duró aún después de muerto. Hay constancia de que, tras su muerte, Sigüenza siguió luchando porque el cacicazgo lo mantuviera el hermano de Juan, Diego de Alva Cortés, interviniendo siempre en favor de esta parte de la familia. En contra de dichas pretensiones estaba Felipe — hijo de Luis de Alva, hermano del renombrado historiador-, quien había heredado de su padre la reclamación de dicho cacicazgo. Véase Edmundo O’Gorman en Ixtlilxochtitl, Fernando de Alva: Obras Históricas, México, 1975, vol.1, págs. 40-42. Deduzco que a cambio de su defensa, Juan de Alva pagó en vida a Sigüenza con su archivo, aunque desafortunadamente no poseemos documentos que puedan demostrarlo. 
lo aquí copiado de Herrera de Cealcoquin, la cual, año de 1680, cuando me volví á Filipinas, dexé al Sr. D. Cárlos de Sigüenza y Góngora [...] juntamente con un cuaderno manuscripto de mas de cincuenta y dos fojas de noticias de haber predicado en Nueva España Santo Tomás Apóstol”?

El manuscrito que da noticias del apóstol Santo Tomás es la obra en la que Sigüenza se basó para escribir el Fénix de Occidente. En base a esto, Chavero deducía que esa historia pintada era La Pintura de la Peregrinación de los culhuas-mexitin que aquí se trata, pues, como también conviene saber y según el padre Clavijero, Sigüenza no sólo formó su colección en base al legado del cacique anterior, sino que asimismo compró algunas pinturas por un alto valor. ${ }^{8}$

Ahora bien, la comprara o la recibiera de Juan de Alva o del padre Duarte, lo que sí puede afirmarse con seguridad es que, a su muerte, Sigüenza dejó sus papeles en herencia a la biblioteca del Colegio de los jesuitas de San Pedro y San Pablo de la Ciudad de México, como consta en su testamento:

“[...] mandó se les entregue a sus padres diferentes libros manuscritos [...] parte de ellos en castellano y parte en lengua mexicana, y los más de ellos originales [...] motivo que me obliga a que solicite se conserven separadamente en parte tan segura [...], en la dicha librería del Colegio Máximo del Señor San Pedro y San Pablo". ${ }^{9}$

Allí fueron consultados —entre 1736 y 1743 - por el viajero italiano Lorenzo Boturini, quien, además de realizar numerosas copias, adquirió gran parte de aquellos documentos para su nueva colección. ${ }^{10}$ La Pintura de la Peregrinación figura así en sus inventarios de 1743, 1745 (4-4) y 1746 (7-6):

"original [dice en el margen derecho, sin precisar de donde lo obtiene].Otro Mapa en papel Indiano, grande como un pliego de marca mayor. Representa las peregrinaciones de la Nación Mexicàna, y su morada en Chapultèpec". ${ }^{11}$

7 Chavero, Alfredo: México a través de los siglos, Barcelona, 1884, vol. I, pág. 263.

8 Clavijero, Francisco Javier: Historia Antigua de México, México, 1945, vol. I, pág. 53.

9 Trabulse, Elías: Los Manuscritos perdidos de Sigüenza y Góngora, México, 1988, pág. 19.

10 Según Trabulse, y en base a Glass, de los 20 volúmenes que el italiano llegó a reunir, la mitad eran de la colección de Sigüenza, compuesta originalmente de 28 volúmenes. Ibídem, pág. 478.

11 Boturini Benaducci, Lorenzo: Idea de una Nueva Historia General de la América Septentrional, México, 1746, pág. 11.Véase también la obra de este mismo autor en su edición de 1974, págs. XXXVIII, XXXIX, y Glass, John: Handbook..., vol. 15, tabla 2, págs. 473-483. 
Algunos autores ${ }^{12}$ han ignorado a Boturini como propietario del documento en base a las palabras del mismo Clavijero:

"Las imágenes del siglo mexicano, la peregrinación de los aztecas y los retratos de los reyes mexicanos, que publicó Gemelli en el sexto tomo de su Vuelta al mundo, son copias de las pinturas de Sigüenza, que vivía en México cuando llegó Gemelli... [Sigüenza] las dejó en su muerte al colegio de San Pedro y San Pablo, de los jesuítas de México, juntamente con su selectísima librería y sus excelentes instrumentos matemáticos. En ella vi y estudié el año 1759 algunos volúmenes de aquellas pinturas...". ${ }^{13}$

No hay duda de que Clavijero visitó el Colegio, pero probablemente la Pintura ya no estaba allí. De otra manera, no se explica por qué, cuando él reprodujo un detalle de ella en su obra (figura 2), no lo hizo en base al documento que allí dejó Sigüenza, sino que lo hizo según el modelo de una copia de autor desconocido, quien le dio un sentido inverso a la imagen (véase el número 2 del apartado sobre copias).

Descartado Clavijero como poseedor de la Pintura, resulta obvio que fue Boturini el que se la apropió junto a otro sinfín de documentos para su Museo Indiano. Algo que no debe causar sorpresa cuando el mismo sobrino de Sigüenza menciona que ya echaba de menos algún libro de la Biblioteca, mientras que Veytia habla del deseo de la gente de apoderarse de todo lo que pudo a la muerte de Sigüenza. ${ }^{14}$

A fines de 1743 tiene lugar la expulsión de Lorenzo Boturini de México. Entonces, su colección comienza a mermar entre traslados, exposiciones y préstamos a distintos investigadores, hasta que finalmente fue abandonada en los sótanos del palacio virreinal según unos, o en la biblioteca de la Universidad según otros. ${ }^{15}$ Trabulse dice que fue en dicho pala-

12 Éstos son: Isidro R. Gondra en Prescott, William H: Historia de la conquista de México, México, 1846, vol. 3, págs. 1-2; Chavero, Alfredo: México a través..., vol. 1, pág. VIII, y Carrera Stampa, Manuel: "Códices, mapas y lienzos acerca de la cultura nahuatl", Estudios de Cultura Nahuatl, México, 1965, vol. V, pág. 177. Todos deducen que tras la expulsión de los jesuitas, en 1767, la Pintura llegó a manos de León y Gama, su siguiente poseedor.

13 Clavijero: Historia Antigua..., vol. I, pág. 50.

14 Según información de Eguiara y Eguren y Veytia en Burrus, Ernest J.: "Clavigero and the lost Sigüenza y Góngora Manuscripts”, Estudios de Cultura Náhuatl, México, 1959, vol. I, pág. 63. El mismo Eguiara y Eguren estuvo en el Colegio en 1752, comprobando que de los 28 volúmenes legados por Sigüenza, tan sólo quedaban 12, bien porque fueron transferidos a otro sitio, fueron robados o bien porque no estaban marcados como pertenecientes a Sigüenza (ibídem, pág. 65).

15 José Ruben Romero Galván en Chimalpahin Cuauhtlehuanitzin, Francisco de San Antón Muñón: Octava Relación, México, 1983, pág. 27, y Burrus: “Clavigero...”, vol. I, págs. 68-70 respectivamente. Este último, en base a las cartas que se escribieron León y Gama y el jesuita Andrés de Cavo, afirma que tras la expulsión de los jesuitas, en 1767, los manuscritos de Sigüenza fueron llevados a la Universidad de donde desaparecieron, junto con los de Boturini, entre 1780-1790. 


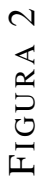

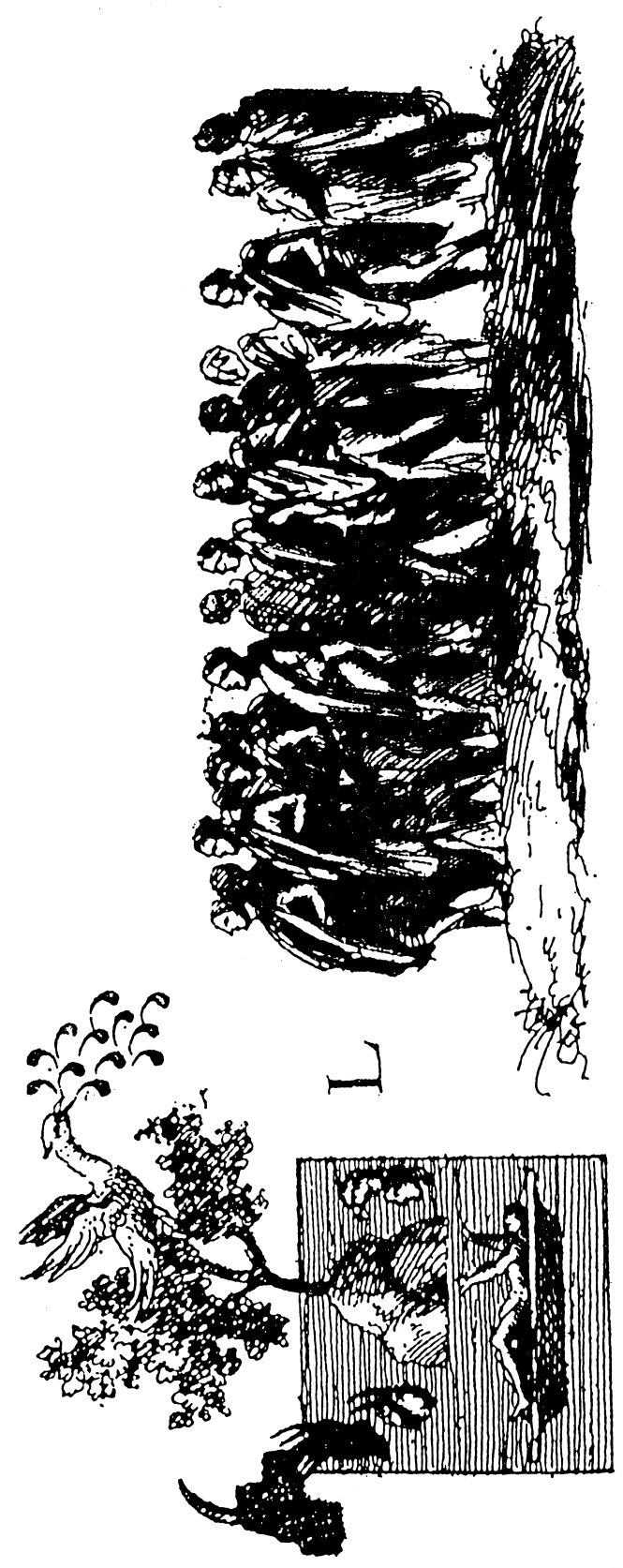


cio donde el historiador mexicano Antonio de León y Gama adquirió el documento en $1784 .{ }^{16}$ En una de sus cartas escrita en 1796 al exiliado jesuita Andrés de Cavo dice lo siguiente:

"Sobre lo que V. me dice de impedir que salgan de aquí los monumentos mexicanos, ni soy árbitro para ello, ni es ya tiempo. Habrá 5 años que se llevaron a España todos los que existían en la Universidad; pero hay dispersos algunos en poder de particulares [...] tuve la fortuna de que declararan las más de las pinturas y los manuscritos mexicanos como cosas que no entendían [...] Con estos documentos y con los que antes había adquirido y otros que conseguí después, me dediqué a procurar su inteligencia, y de la lengua mexicana, que ignoraba". ${ }^{17}$

Sin duda, entre esos documentos que adquirió estaría La Pintura de la Peregrinación, como se puede deducir de la copia que le sacó.

A su muerte, en 1802, el documento pasó a su albacea el padre Pichardo, razón por la que Alexander von Humboldt, en su visita a México al año siguiente, no lo halló. El rastro se hace difícil a la muerte de Pichardo en 1812; de los seis mil volúmenes que llegó a reunir en la biblioteca de La Profesa, una parte quedó en ella, otra se dividió entre la biblioteca de la Universidad y la de la Catedral, y una tercera regresó a los herederos de León y Gama. Éstos, debido a las penurias económicas que la familia atravesaba, vendieron en 1830 una parte a Josep M. Alexis Aubin, quien se la llevó consigo a París. En ese lote debían ir las copias de León y Gama y las realizadas por el Padre Pichardo, que hoy se hallan en la Biblioteca Nacional de la capital francesa. La Pintura de la Peregrinación, sin embargo, permaneció en México. Isidro R. Gondra, conservador del Museo de Antropología de México en los años 40, da noticias de que fue comprada de la testamentaría del padre Pichardo por el doctor José Vicente Sánchez, quien la donó a dicha Institución. ${ }^{18}$

\section{El robo del Museo}

Como ya anuncié en la introducción, he dedicado un apartado al tema del robo, no sólo por la conmoción que causó su aparición, sino también

16 Trabulse: Los Manuscritos..., pág. 31.

17 Burrus, Ernest: “Clavigero...”, vol. I, págs. 70-71. El subrayado es mío. Orozco y Berra nos informa de que el concienzudo trabajo que León y Gama realizó para comprender la documentación recogida tuvo como resultado una voluminosa obra, hoy desaparecida. Orozco y Berra, Manuel: Historia Antigua y de la Conquista de México, México, 1978, vol. I, lib.I, cap. IV, pág. 338.

18 Isidro R. Gondra en Prescott: Historia..., vol. 3, pág. 1. 
por el largo proceso de su recuperación, lo insólito del caso y la falta de información más allá de los periódicos del momento.

Como ya se dijo, José Vicente Sánchez donó la Pintura al Museo, sin quedar muy claro lo que sucedió después:

"El jeroglífico de Sigüenza no está en el Museo y acaso no vuelva á él: por fortuna tenemos una copia en papel de calco, exactísima en figuras, colores y tamaños, que perteneció al señor Ramírez". ${ }^{19}$

Sobre esta "misteriosa" desaparición, Glass solamente nos dice que salió del Museo hacia 1867-1871. ${ }^{20}$ Se trata precisamente de los años en los que la instauración del emperador Maximiliano en México causó grandes desórdenes en todo el país. Durante su gobierno, concretamente en 1865, Maximiliano mandó que todo el Museo se trasladara al edificio de la calle de la Moneda (calle Emiliano Zapata). A partir de entonces el rastro de la Pintura se pierde. Se pensó que a la caída del Imperio quedó abandonada junto con otros manuscritos en la bodega de Minería, donde Chavero halló la Tira de la Peregrinación, además de otros documentos que restituyó al Museo en marzo de $1871 .{ }^{21}$ Sin embargo, la Pintura no estaba allí. No es hasta 46 años después de su desaparición, en 1904, que su nombre vuelve a salir a la luz:

"Hace muchos años que este valioso documento salió del abrigo del 'Museo Nacional' sin dejar ninguna huella. Una mañana de la primavera pasada, al entrar en un almacén de la calle Coliseo, en México, se le presentó en una partida de antigüedades a un sacerdote oriundo de los Estados Unidos, bien conocido por todos los mexicanistas, el reverendo Hunt Cortés. Éste reconoció en seguida el carácter y el valor del precioso lienzo. Dejaremos a un lado el detalle de la larga investigación que se inició entonces, las polémicas que se entablaron referente a esto en la prensa y en el mundo sabio (unos llegaron incluso a pretender que el manuscrito milagrosamente encontrado no era nada más que una simple copia), la versión oficialmente admitida para explicar la desaparición del 'Mapa'. El hecho interesante, el único que tenemos que conocer, y del cual nos alegramos, es que el 'Lienzo' fugitivo regresó, para el mayor provecho de los estudios mexicanistas, al domicilio legal del que nunca hubiera tenido que salir". ${ }^{22}$

19 Chavero, Alfredo: "Sigüenza y Góngora", Anales del Museo Nacional de México, vol. III, México, 1886, págs. 473, 474.

20 Glass, John: Catálogo de la colección de códices, México, 1964, pág. 54.

21 Alfredo Chavero en el Apéndice de Durán, fray Diego: Historia de las Indias de Nueva España e islas de tierra firme, México, 1880, pág. 113.

22 Lejeal, León: "Les vicissitudes d'un 'Lienzo mexicain'”, Journal de la Société des Américanistes, Nouvelle Série, vol. I, núm. 2, París 1904, pág. 383. El subrayado es mío. Agradezco a Michael Swanton, Nadia Prévost Urkidi y Delphine Tempere la traducción que me hicieron del texto original en francés. 
¿Por qué hay tan poca información de los hechos?, ¿dónde estuvo entonces el documento durante todos esos años?, ¿por qué Lejeal parece querer "echar tierra sobre este asunto"? Siguiendo entonces la pista que proporciona el mismo Lejeal, al decir que en los periódicos se habló mucho del tema, esperé a llegar a México para leer los diarios de la época, teniendo asimismo la oportunidad de consultar el informe final redactado por la Secretaría de Justicia e Instrucción Pública y el de varios peritos que tomaron cartas en el asunto. ${ }^{23}$ El periódico consultado fue El Imparcial del año de $1904,{ }^{24}$ el cual ciertamente hizo un exhaustivo seguimiento del suceso, como a continuación el lector tendrá oportunidad de comprobar.

La primera noticia que se tiene de su aparición la recoge este diario en su portada del viernes 25 de marzo, donde informa que la tienda de antigüedades que lo puso a la venta era propiedad de los hermanos Galván, y que iba dentro de un lote con una serie de planos y copias de jeroglíficos antiguos. Le fue ofrecido al reverendo Hunt Cortés, quien al reconocer el valor del documento informó al director del Museo. ${ }^{25} \mathrm{El}$ lote en el que iba el documento estaba tasado en 15.000 pesos y no podía venderse por separado.

El asunto fue entonces puesto en manos de la autoridad federal, iniciándose una serie de pesquisas a través de la Secretaría de Justicia. La primera información que se obtuvo fue que su propietario era un tal Hipólito Ramírez, averiguándose inmediatamente que era hijo de José Fernando Ramírez, quien fue director y conservador del Museo Nacional. Paralelamente, un reportero del diario fue a ver a Chavero para hacer averiguaciones y éste informó que cuando rescató los documentos del Palacio de Minería echó en falta el "plano de la peregrinación", pensando que pudo haber sido robado debido a que una de las rejas de la sala donde se hallaban estaba forzada. ${ }^{26}$

23 Todo ello está en el Archivo General de la Nación (en adelante AGN), Instrucción Pública y Bellas Artes, Ministerio de Justicia e Instrucción Pública, grupo 10, caja 167 bis, exp. 68, "Códice antiguo mexicano, mayo de 1904". Agradezco a Sebastián van Doesburg esta información.

24 Hemeroteca Nacional (UNAM) y Hemeroteca de la Biblioteca Nacional de Antropología e Historia. El Imparcial, 1 de marzo al 1 de junio de 1904.

25 Dos días después, el periódico precisa que el informado fue el ingeniero García Cubas, buen conocedor del documento por haberlo publicado en su gran obra de 1858, como se verá más adelante. García Cubas lo comunicó al jefe del Departamento de Arqueología del Museo, el Sr. Galindo y Villa, siendo éste quien lo puso en conocimiento de su director.

26 Al parecer, según las palabras de Chavero a este periódico, al finalizar la intervención francesa y en los momentos más críticos, Manuel Orozco y Berra ideó poner a salvo los documentos que el Museo guardaba. Habló con el director de la Escuela de Minería, quien le cedió un departamento para que depositara todos los objetos de valor de dicho Museo. En 1871, Chavero supo de esto y fue a recuperarlos, comprobando que una viga del techo había caído sobre ellos, razón por la que éstos se mancharon de agua. Para remediarlo los puso al sol, salvando la mayoría de ellos (El Imparcial, 25 de marzo). 
El domingo día 27 de marzo, el periódico informaba de que el señor Ramírez, hijo de José Fernando Ramírez, aún no había declarado. Que, sin embargo, fue a la redacción del periódico, siendo importante aquí reproducir sus palabras:

“[...] el lienzo geroglífico era de la propiedad exclusiva del señor su padre, quien lo adquirió el año 1858 por haberlo comprado, por conducto de corredor titulado, á un indígena de un pueblo cercano, junto con otro lienzo muy notable que explica la llegada de Hernán Cortés á Tlaxcala, y unos títulos de noblezas auténticos concedidos por el Rey de España á un traxcalteca [sic], en virtud de la ayuda que éste impartió á Cortés. Agrega [...] que es público y notorio que su padre gastó mucho dinero en documentos históricos y geroglíficos de antes y después de la Conquista, que era un perito en arqueología y que su propia [honra]dez estuvieron siempre fuera de duda; que el señor Chavero sufre una equivocación en el presente caso, porque dicho Cuadro Histórico y Geroglífico que explica la peregrinación de los aztecas, hoy recogido por la autoridad, no estuvo depositado en Minería". ${ }^{27}$

Ante tanta confusión, el periódico de aquel día concluía el tema con la siguiente frase:

"De peso diremos aquí que nadie trata de herir, ni puede ser herida la memoria de Don José Fernando Ramírez que consagró su vida á la ciencia, que enriqueció la Historia Patria y que en lo personal fué un modelo de virtudes". ${ }^{28}$

No obstante, la edición del martes 29 de marzo no es menos importante al reiterar lo siguiente:

“El señor Don Hipólito Ramírez insiste en afirmar que dicho cuadro perteneció á su padre Don José Fernando, y que por tanto á él le corresponde hoy por derechos hereditarios.

Agrega el señor Ramírez que se trata no de una copia, sino del original, aunque reparado ó retocado éste en uno de sus ángulos, por haberse borrado varias figuras [...]". ${ }^{29}$

Ante esta situación se llama a declarar al ingeniero Antonio García Cubas, puesto que él conoció el cuadro y lo publicó en 1858 en su Atlas, con una explicación escrita por el mismo José Fernando Ramírez, en la cual, además de juzgar dicha pintura como el monumento histórico más interesante de la antiguedad mexicana, dice ser el poseedor de una antigua y muy fiel copia de las dimensiones del original.

27 Ibídem, 27 de marzo.

28 Ibídem.

29 Ibídem, 29 de marzo. 
"El monumento histórico que tenemos á la vista, uno de los mas auténticos é interesantes de la antiguedad mexicana, es quizá tambien el mas célebre de los conocidos [...] se conserva en el Museo nacional, y tal cual hoy existe tiene setenta y siete y medio cent. de longitud por cincuenta y cuatro y medio de latitud, presentando rastros de cercenacion en sus márgenes probablemente al enlenzarlo, bien que sin daño de sus figuras. Está escrito en papel de maguey de la clase mas fina; circunstancia que unida al descuido y desprecio con que antiguamente se veian esa clase de objetos, produjo el lastimoso estado de deterioracion en que se encuentra. Partido por los cuatro dobleces en que se le conservaba, perdió ademas dos ó tres figuras, de que solo quedaron algunos rasgos: han completádose con el auxilio de una antigua y muy fiel copia que yo poseo, de las mismas dimensiones que el original". ${ }^{30}$

Una copia que, según declaración tomada al historiador Luis González Obregón, éste vio en casa de Hipólito Ramírez. Según él, difería del original "[...] en el color del papel, pues que el de la cópia es mas blanco, carece de dobleces y tiene completas las figuras". ${ }^{31}$ Entonces hay que recordar que al principio de este apartado vimos una cita en la que Chavero decía poseer la de su mentor, siendo contradictorio que no la sacara a relucir en este delicado asunto.

Llegados a este punto, y de acuerdo con el periódico, se concluye que en 1858 el documento se conservaba en el Museo Nacional - que pertenecía por tanto a la Nación-, mientras que una copia muy fiel y de exclusiva propiedad era guardada por Ramírez. Quedaba así por determinar si la que estaba en posesión de Hipólito Ramírez era el original o la copia, aunque éste, como arriba se ha dicho, defendió en todo momento que se trataba del original. Una situación en la que la autoridad judicial ve indispensable la intervención de personas expertas, no sólo en la historia antigua sino también en la de sus documentos jeroglíficos. Deciden entonces nombrar a dos peritos: el ingeniero Antonio García Cubas y el jefe del Departamento de Arqueología del Museo Jesús Galindo y Villa, quienes, según la copia del informe que se guarda en el Archivo General de la Nación, centraron sus exámenes en comparar el manuscrito que tenían en sus manos con las descripciones que del mismo hizo Ramírez. Entre éstas cabe citarse las dimensiones del documento, el deterioro del conjunto, ${ }^{32}$ la cercenación de

30 García Cubas, Antonio: Atlas geográfico, estadístico e histórico de la República mexicana, México, 1858, carta 32, Cuadro histórico-geroglífico I.

31 Copia del informe oficial que se conservan en el AGN, pág. 14v.

32 Punto determinante para sus conclusiones ya que observan que al documento que examinan le faltan todavía las figuras del ángulo superior izquierdo, lo cual era fundamental para concluir que el que tenían en sus manos no era la copia que sirvió para completar el original, ya que aquella debió estar íntegra para que pudiera servir, no solo de auxiliar, sino también de complemento. (Ibídem, pág. 7). 
los márgenes, la escritura de algunos vocablos o la división del amate en cuatro partes debido a sus dobleces. Un análisis tan exhaustivo que hasta, para confirmar la naturaleza del fino papel de fibra vegetal, recurrieron al dictamen de un técnico. Con respecto a esto concluyen:

"[...] son detalles que, como decíamos, coinciden de una manera patente y notable con nuestro documento. Sería asombroso que en una simple copia, por más fiel que se la suponga, se reuniera este pasmoso conjunto de circunstancias, que inclinan de modo irrefutable, al convencimiento de que este es el mismo original que, para reproducirlo y describirlo, tuvo en sus manos el ilustre y venerado fundador de nuestra arqueología don Jose Fernando Ramírez.

Los facsímiles de códices originales que en estos últimos tiempos se han dado á la luz por personas distinguidas, muestran los dobleces, roturas, polillas, etc., de los autógrafos, pero dibujados, de tal suerte que produzcan una ilusión, un efecto de la realidad, pero nunca la realidad misma. Esto es tan claro y evidente, que no ha menester más explicación para comprenderse". ${ }^{33}$

El dictamen es definitivo. A él es importante añadir nuevamente la declaración de Luis González Obregón por sus interesantes aportaciones acerca del documento. Dijo que hacia 1858 iba mucho a la Universidad de México, donde entonces estaba el Museo, y que allí copió y estudió numerosos documentos antiguos, entre ellos La Pintura de la Peregrinación de los culhuas-mexitin, que entonces estaba en un cuadro y bajo cristal. Pero que un día le extrañó no verla y que indagando, los empleados del Museo le informaron que estaba en casa de Ramírez, quien lo tomó para publicarlo en el Atlas. ${ }^{34}$ Después de todo esto, a pesar de la amplia declaración de Hipólito Ramírez en la que dice probar mediante informes que el documento perteneció a su padre, El Imparcial del viernes 8 de abril concluye:

"A pesar de esta afirmación [la del hijo de J. Fernando Ramírez], prevalece la creencia de que el repetido cuadro se hallaba como prestado ó en calidad de depósito en la casa del señor Don José Fernando Ramírez, quien sin duda al morir no pudo explicar el asunto y sus deudos creyeron que aquél pasaba á su poder por razón de herencia [...] El señor Don Hipólito Ramírez ha dicho en lo particular, que cree fundadamente en sus derechos que ha alegado, pero que si á la Nación le interesa poseer el cuadro jeroglífico, no tiene incoveniente en cederlo". ${ }^{35}$

33 Ibídem, págs. 6-7.

34 Ibídem, págs. $14 \mathrm{r}-15 \mathrm{r}$.

35 El Imparcial, 8 de abril. 
Por su parte, en el informe oficial consta lo siguiente:

“[...] se desprende que el señor D. Fernando Ramírez conservó el documento de que se trata aún despues de públicado el Atlas sin haberlo devuelto al Museo, seguramente á causa de los trastornos politicos de aquella época, pues la reconocida y notoria honorabilidad del expresado señor Lic. Fernando Ramírez, no permiten hacer alguna otra suposición". ${ }^{36}$

Lo sorprendente del caso es que éste finaliza con unos argumentos muy diferentes a los que comenzó. Un hecho que se observa no sólo en el periódico, sino también en el informe final que la justicia emitió y con el cual cerró el caso. Comencemos con los datos de El Imparcial del 1 de mayo:

"Ha tocado á su fin la averiguación practicada [...] con motivo de haberse encontrado [...]un Códice Azteca, que resultó ser de propiedad de la Nación.

La averiguación tuvo por objeto investigar si se había cometido el robo de ese importante documento histórico, y en caso de existir delito, perseguir al que resultase responsable.

Por las diligencias practicadas se vino á saber: que el último poseedor del Códice había sido el señor Licenciado Don Hipólito Ramírez, que lo conservaba en su poder desde la muerte de su padre, el señor Licenciado José Fernando Ramírez, Conservador que fué del Museo Nacional, de donde tomó el Códice para estudiarlo y describirlo en el "Atlas Geográfico Histórico y Estadístico de la República Mexicana" que se formó el año de 1858.

En efecto, en dicho Atlas apareció reproducido el Códice de la Peregrinación Azteca. El Licenciado Hipólito Ramírez no entregó el Códice al Gobierno, porque estaba en la creencia de que no era el original, sino una copia: pero en cuanto supo, por el dictamen de los peritos Ingenieros [...] que el documento era el original, propiedad del Museo, lo puso á disposición de la Nación, como lo dispone el artículo 710 del Código Civil" ${ }^{37}$

Respecto a lo que recoge el informe pericial en sus páginas 13r-14r, puede leerse que, cuando Hipólito Ramírez fue a declarar, dijo que consideraba el documento una copia del original, que siempre lo creyó una copia y que por ello nunca le dio importancia. Ahora bien, que sabiendo por el propietario del bazar de antigüedades que había una persona interesada en sus documentos, se le manifestó que si ofrecía un buen precio se le vendería, pero con la precisa condición de proponer la operación al Gobierno.

Sobreseído el caso y después de tantas vicisitudes, es así como el documento fue restituido al Museo en mayo de 1904.

36 AGN, ..., pág. 15 r.

37 El Imparcial, 1 de mayo. Las cursivas son mías. 


\section{Copias que se generaron}

En la actualidad se conservan algunas copias de la Pintura en distintas partes del mundo. Algunas han sido insertadas en las obras o estudios de diferentes autores, siendo simplemente designadas como Mapa de Sigüenza. Es decir, sin especificar que se trataba de una copia del manuscrito pictográfico original y, en tal caso, qué copia reproducía y dónde se conservaba. Asimismo, algo sorprendente sucedió cuando, buscando una reproducción en determinado libro, se pudo comprobar que ésta no existía y que tan sólo recogía un detalle muy parcial de la misma. Por ello, la labor que se ha realizado es la de examinar las distintas reproducciones que se han logrado identificar a través de referencias o publicaciones. Algunas de ellas podrán compararse al haber sido insertadas al final del presente trabajo. Han sido ordenadas por orden cronológico y son las siguientes:

1. La de Giovanni Francesco Gemelli Carreri (figura 3). Es a primera copia de la que se tiene constancia. Este viajero italiano la realizó cuando, recorriendo México a fines del siglo XVII, entró en contacto con Sigüenza, quien, según sus palabras, le permitió ver el original:

“[...] de tal modo que la figura del ciclo mexicano y otras antigüedades de los indios, que en seguida vendrán representadas en este volumen, se deben todas a la dilligencia y a la cortesía de Sigüenza, que me hizo don de tan peregrinas rarezas". ${ }^{38}$

Se trata de una litografía, en blanco y negro, que insertó en el volumen VI de su Giro del Mondo (1700) y que ha sido la base de numerosas copias posteriores. ${ }^{39}$ No obstante, la reproducción de este viajero italiano dista mucho del original, ya que su estilo romántico — según el gusto de la época - invade todo el documento. De todas maneras es interesante señalar que en su copia puede verse como Gemelli, además de añadir algunas anotaciones en italiano, también tradujo los nombres de la mayoría de los topónimos en la misma lengua. Asimismo, llevó a cabo sus propias interpretaciones de los glifos cuando éstos carecían de glosa, ignorando o cambiándole el nombre a aquéllos que lo tenían impreso en el original y con los que no estaba de acuerdo. Debido a que Gemelli carecía de los conocimientos suficientes para esta labor, se cree que los cambios pudieron haber sido dictados por el propio Sigüenza.

38 Gemelli Carreri: Viaje..., lib.I, cap.V, págs. 52, 55.

39 Gemelli Carreri, Giovanni Francesco: Giro del Mondo, Nápoles, 1700. El volumen VI de esta obra es el que incluye el Viaje a la Nueva España. 


\section{LA PINTURA DE LA PEREGRINACIÓN DE LOS CULHUAS-MEXITIN}

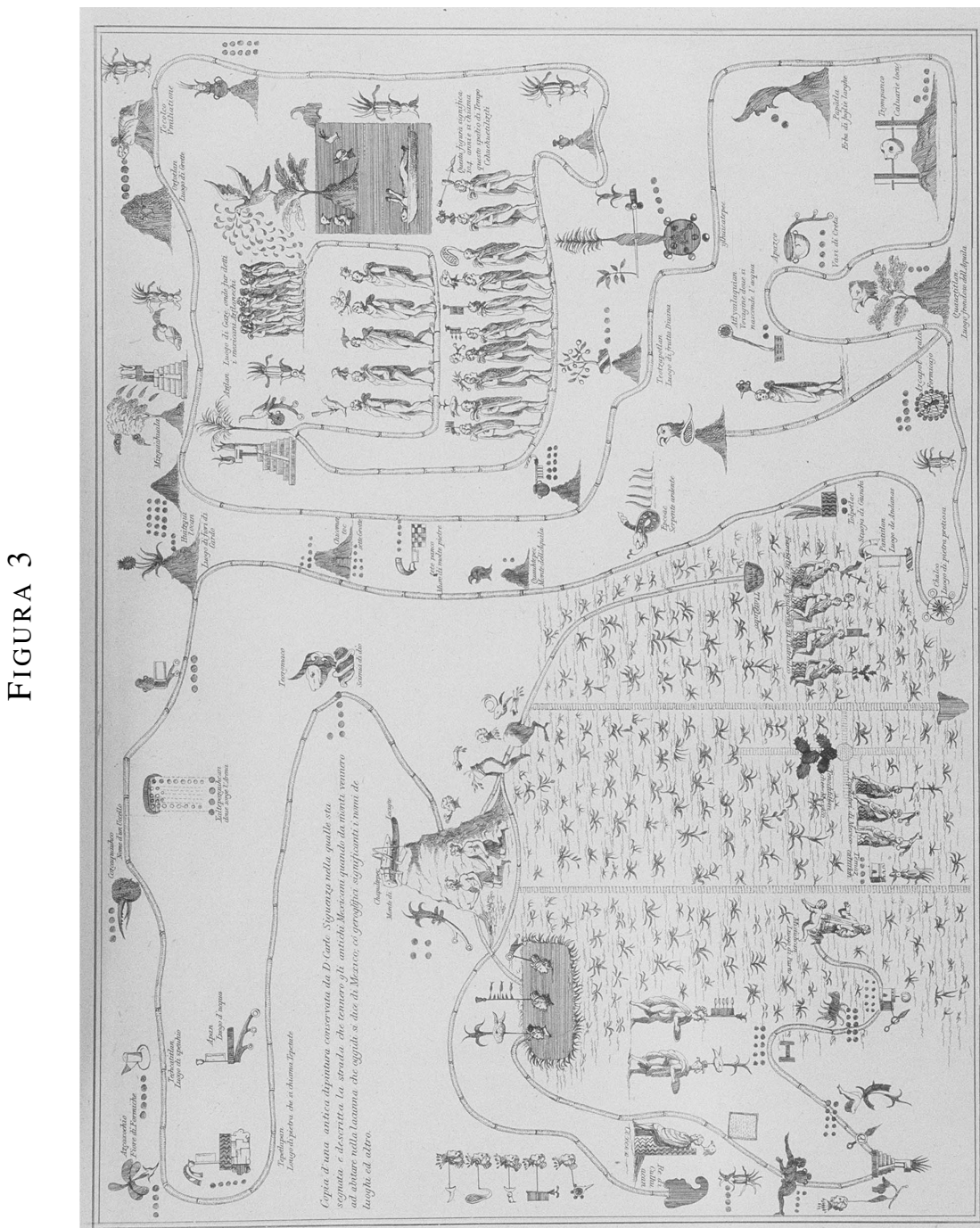


Su libro fue algo así como el "best-seller" de la época, motivo por el cual fue traducido a varias lenguas. En este punto es interesante observar que no fue sólo el texto de su obra el que se tradujo a uno u otro idioma, se hizo lo mismo con las glosas y anotaciones que acompañaban a sus dibujos. Así se ha observado en la copia de la Pintura de la edición francesa de 1727 o en la inglesa de 1757.40

2. Copia de autor desconocido. Se ha considerado como copia aquella que se halla inserta en las ediciones que se hicieron del Giro del Mondo en 1927 y 1976, y que ha sido motivo de grandes confusiones. ${ }^{41}$ Se trata de un documento que merece especial atención porque, a primera vista, es muy semejante al de Gemelli, aunque si se mira con mayor detenimiento podrán observarse importantes divergencias (véase la de Von Humboldt - figura 4-, cuya copia es una fiel reproducción de ésta, aunque sin textos).

En primer lugar, la reducción a la que se vio sometida el área lacustre, que tuvo que ser restringida casi a la mitad de su superficie por falta de espacio, quedando el canal que atraviesa Tenochtitlan de este a oeste con una longuitud muy corta. La consecuencia de este error repercute en la disposición de los últimos glifos, así como en la distribución de algunos de los señores fundadores, llegándose a alterar incluso su orden. En segundo lugar, el interesante fenómeno de reproducir el documento con efecto de espejo, como si se hubiera proyectado la Pintura con una cámara que dejaba ver tal efecto y así se copió. Es decir, que Aztlan no está en la esquina superior derecha, sino en la izquierda, por lo que, consecuentemente, Tenochtitlan queda situada en el borde inferior derecho, dando como resultado un sentido opuesto a la lectura del manuscrito. Las deficiencias no terminan aquí; en tercer y último lugar, en el intento de copiar las glosas de Gemelli se cometieron una serie de errores de ortografía que parecen indicar que su autor o autores no entendían la lengua y, por consiguiente, que no eran italianos. ${ }^{42}$

40 Gemelli Carreri, G.F.: Voyage du Tour du Monde de la Nouvelle Espagne, París, 1727, vol. VI y Gemelli Carreri, G.F.: "A Voyage round the World", A Collection of Voyages and Travels, Some now First Printed from Original Manuscripts, Others Now First Published in english, London, 1757, vol. IV.

41 Gemelli Carreri: Viaje..., México, 1927 y 1976.

42 La autora del estudio de la obra de Gemelli de la edición de 1976, Francisca Perujo, dice seguir la edición de Nápoles de 1728, si bien conocía y también consultó la de México de 1927. Entonces no se comprende por qué no reparó en estas divergencias. Lo mismo sucede con el estudio de José María de Agreda arriba referido, el de 1927. Este autor dice traducir los escritos de Gemelli directamente del texto original y en vista de la edición príncipe. Nuevamente, no se explica por qué incluye en su obra la reproducción inversa y no la recogida directamente por Gemelli. 


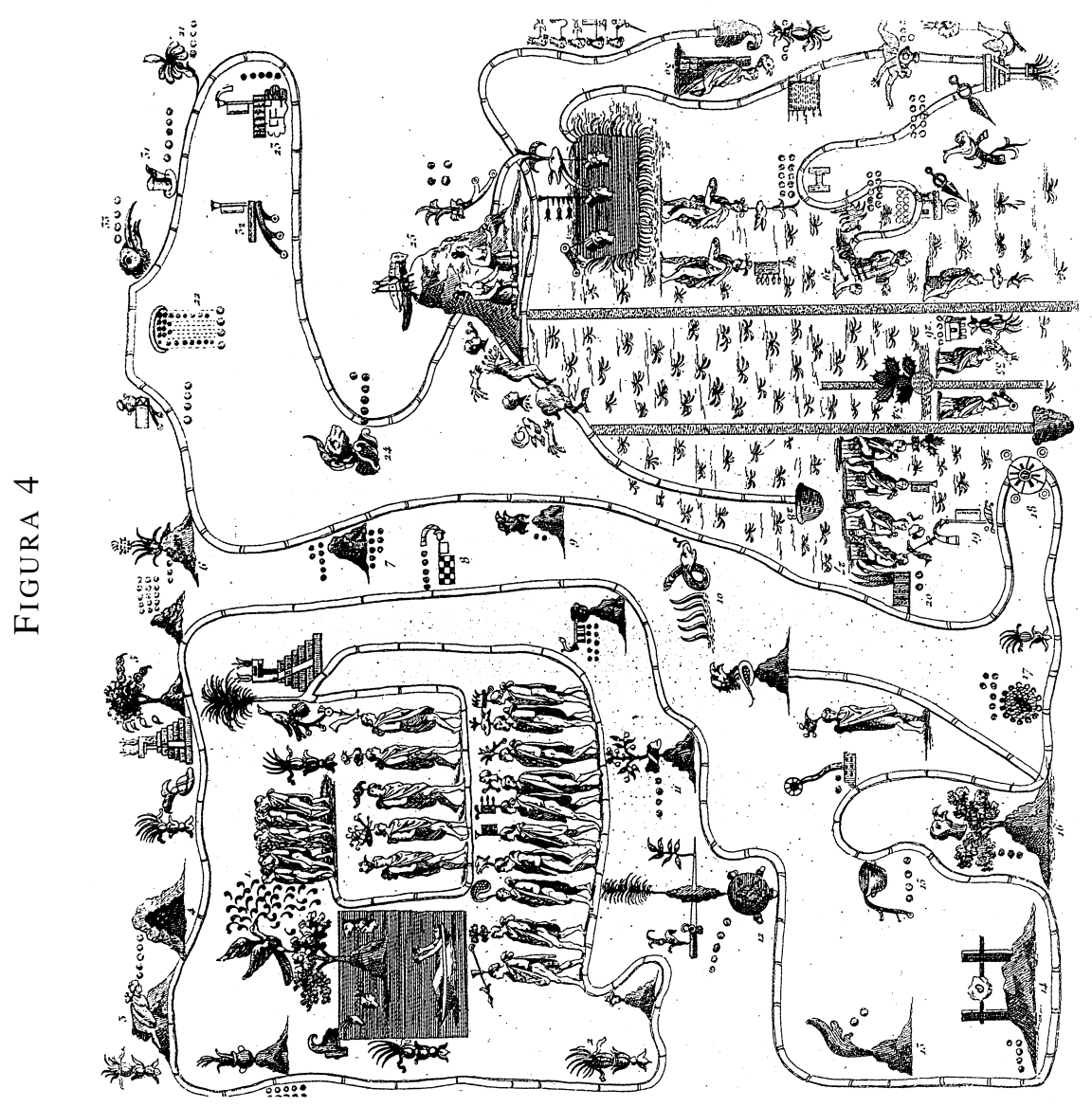


Este aspecto se ha consultado con varios colegas y amigos, algunos de los cuales han contemplado la posibilidad de que se trate de un grave error de la persona encargada de elaborar las planchas que reproducían el documento y no de una copia intermedia. Sin embargo, en mi opinión ambas teorías son posibles, sin poder dar todavía una respuesta satisfactoria sobre el asunto. Ahora bien, el motivo por el que la he clasificado como copia es porque, aún contemplando la posibilidad de que sea un error que viene de imprenta, el resultado ha sido el de un documento diferente.

3. La copia de Francisco Javier Clavijero (figura 2). Este autor franciscano escribe su Storia Antica del Messico en Bolonia (Italia), a su vuelta de México. ${ }^{43}$ Sin embargo, en ella no incluye una reproducción entera de la Pintura de la Peregrinación, como en alguna ocasión se había dicho, ${ }^{44}$ sino tan sólo un detalle de la misma, litografiado y en blanco y negro, como aseveran Orozco y Berra y Chavero. Se trata de aquel que representa Aztlan-Teoculhuacan, con el dios dirigiéndose al grupo que tiene ante sí. En su momento se mencionó que Clavijero estuvo en el Colegio de los Jesuitas en 1759, donde tuvo la oportunidad de consultar los papeles de Sigüenza. Sin embargo, probablemente el manuscrito original ya no se encontraba allí pues para su copia nunca se basó en él. Quizás la hiciera a su vuelta en Cesena, pero no en base a la copia de Gemelli, a la que en varias ocasiones se refiere en su obra, sino que recurrió a la copia del autor desconocido, dándole el mismo sentido inverso a las figuras. ${ }^{45}$ En este punto cabe comentar que su dibujo, recogido en la primera edición de su libro (1780-1781), difiere en gran medida de su otra edición de 1945 usada también para este trabajo. ${ }^{46}$ Mientras en la obra más antigua los trazos son rápidos y bruscos, borrando la tinta cualquier apreciación del detalle, en la edición más reciente se hace mucho más detallado y cuidado, apreciándose las caras de los personajes y el movimiento de los ropajes.

4. La copia de Antonio León y Gama (1736-1802). Gracias a las constantes cartas que este historiador escribía al ya mencionado jesuita Andrés de Cavo, residente en Roma, puede conocerse los orígenes de la copia que en este libro se reproduce:

43 Clavijero, Francisco Javier: Storia Antica del Messico, Cesena, 1780-81.

44 Carrera Stampa: "Códices...”, vol. V, pág. 177.

45 Orozco y Berra: Historia Antigua..., vol. I, lib.1, cap.III, pág. 48, y Alfredo Chavero en el Apéndice de Durán: Historia de las Indias..., pág. 111. Chavero repara en que tan sólo se trata de un detalle y cree que Clavijero se valió del grabado de Gemelli, siendo el sentido inverso del dibujo obra del jesuita.

46 Clavijero: Historia Antigua... 
"Año y medio tuve en casa a un hábil Pintor que me los copió [las pinturas] exactamente, mientras yo hacía lo mismo con lo manuscrito y aun aquellas pinturas que me parecían menos difíciles[...]". ${ }^{47}$

Como se dijo anteriormente, León y Gama tuvo acceso al palacio virreinal en 1784, donde consultó la colección de Boturini. Probablemente allí obtuvo la Pintura que había sido propiedad de Sigüenza, a la que sacó una copia, que es la que hoy se encuentra en la Biblioteca Nacional de París, en el Departamento de Manuscritos Orientales, bajo el nombre de Mexicain 91. Se trata de una reproducción a color muy similar al original, elaborada sobre papel europeo de cierto grosor, que presenta ligeras señales de haber estado plegada en algún momento, siendo su estado de conservación realmente bueno. Con unas dimensiones sensiblemente más reducidas que la Pintura original: $45 \times 63 \mathrm{cms} .{ }^{48}$ sus glifos son de proporciones algo mayores, siendo el ave que representa a Huitzilopochtli un tanto desproporcionada con respecto al árbol que la sostiene. En esta copia, y a través de las tintas, se puede observar como León y Gama, un tiempo después de escribir las primeras glosas en tono rojizo, añadió algunas más, esta vez con una tinta más oscura, en realidad negra. Años más tarde se le añadieron algunas notas a lápiz y otras en tinta, siendo fácil reconocer la mano de Aubin, posterior poseedor del manuscrito.

5. La copia del padre José Antonio Pichardo (1748?-1812). En 1802, este jesuita heredó los papeles de León y Gama, entre los cuales se hallaba la Pintura, así como la copia que aquél realizó. No obstante, Pichardo llevó a cabo una nueva copia, también a color, que asimismo se conserva en la Biblioteca Nacional de París, en el Departamento de Manuscritos Orientales, bajo la designación de Mexicain 89. Realizada en papel europeo, sus márgenes fueron recortados siguiendo una línea negra que la demarca, aunque ésta ha sido sobrepasada en el margen derecho llegando a afectar a la pintura. Sin duda, esto responde a la idea que se tuvo de encuadernarla como se observa en su doblez central, donde todavía son visibles los restos de dicha encuadernación. Actualmente se encuentra enmarcada en cartón blanco que no permite ver su parte posterior, pero hay que decir que su estado de conservación es muy bueno.

47 Burrus: "Clavigero...”, vol. I, págs. 70-71.

48 Así lo registrada Boban, Eugène: Documents pour servir à l'histoire du Mexique. Catalogue Raisonné de la Collection E.-Eugène Goupil (Ancient collection J.M.A. Aubin), París, 1891, vol.II, pág. 245. 
Pichardo reprodujo de manera fidedigna el original conservado en México, si bien descuidó en algo el dibujo en áreas muy concretas, como se observa en las huellas impresas, que por su tamaño rebasan todo el ancho del camino, y en los tules de la zona pantanosa de los alrededores de Chapultepec, que son dibujados con gruesos trazos. Hay que destacar la representación de los personajes que inician la migración, cuyas figuras se acortan con respecto al original.

Como se deduce del registro de sus glosas, Pichardo llevó a cabo su propio estudio interpretativo y, al igual que en la copia de León y Gama, esta reproducción cuenta con una serie de anotaciones y comentarios en francés añadidos por la mano de Aubin, tanto en lápiz como en tinta, siendo la mayoría casi ininteligibles.

6. La copia de Alexander von Humboldt (figura 4). Este viajero alemán, a quien se puede encontrar en México en 1803, buscó vanamente la pintura durante su estancia:

"En vano he hojeado las pinturas aztecas conservadas en la biblioteca de la Universidad: no pude encontrar el original del dibujo que se presenta en la lámina XXXII; pero en México existen varias copias antiguas que, ciertamente, no fueron hechas del grabado de Gemelli Carreri" ${ }^{49}$

La razón de su infructuosa búsqueda parece que se debe a que por entonces el documento pasaba de unas manos a otras, siendo su próximo poseedor el padre Pichardo. No obstante, por lo que se deduce de sus palabras, Von Humboldt tuvo acceso a varias copias que diferían del dibujo de Gemelli. Esto quizás explique que su copia no esté basada en la del italiano sino en la del autor desconocido, otorgándole sus mismas características: el sentido opuesto de la lectura del documento, el reducido espacio dado al área lacustre y la alteración en el orden de los fundadores. Se trata de una reproducción tan fidedigna que apenas hay diferencias entre una y otra. ${ }^{50}$ Von Humboldt tan solo excluyó los comentarios y glosas que acompañaban al dibujo insertado en la lámina XXXII de su obra y que tituló

49 Von Humboldt, Alexander: Vistas de las cordilleras y monumento de los pueblos indígenas de América, 2 vols, México, 1979, pág. 234.

50 Alfredo Chavero en el Apéndice de Durán: Historia de las Indias..., pág. 111. Este autor comenta que se trata de una reproducción de Gemelli, aunque con ciertas difencias. Es obvio que Chavero no conocía la copia de autor desconocido o la edición defectuosa de Gemelli, en la que se basó Clavijero y ahora Von Humboldt. Lo mismo sucede con Boban: Documents pour servir..., vol.II, pág. 246, quien llega a ignorar las diferencias entre la copia de Gemelli y Von Humboldt. Algo similar ocurre más recientemente en el estudio que hace Francisca Perujo a la obra de Gemelli Carreri: Viaje..., págs. LXVIII-LXIX. 
"Historia geroglífica de los Aztecas desde el diluvio hasta la fundación de la ciudad de México".

7. La copia de Isidro Rafael Gondra (1788-1861). Siendo tercer director del Museo Nacional de México en los años 30, fue invitado por el editor de la Historia de la Conquista de México, de William H. Prescott, para realizar un tercer volumen de láminas con algunos de los objetos guardados en el Museo. En él se incluyó una copia de la Pintura de la Peregrinación, con su correspondiente texto explicativo.

"Esta lámina es cópia del precioso manuscrito geroglífico en papel de maguey [...] donación del doctor D. J. Vicente Sanchez [...]". ${ }^{51}$

Debido a la mala calidad de la publicación es imposible reproducirla. Un hecho lamentable, ya que se desconoce de qué copia se trata y quién fue su autor. Gondra tan sólo dice que era un manuscrito jeroglífico que también se conservaba en el Museo, con algunas glosas tan borradas que son casi ilegibles:

"La cópia de la que tratamos tiene algunos letreros que se conoce han sido escritos posteriormente al dibujo, algunos de los cuales están tan borrados que apenas pueden leerse, sin embargo están legibles los siguientes: Oxtotlan, Tetepanco, Cuautepec, Chicomoztoc, ashuatocan, Tepetlastoc y Ameca". ${ }^{2}$

Desconcertantemente, estas tres últimas glosas son del todo ajenas a la Pintura original que se guarda en México, por lo que pueden provenir de su propia interpretación o porque la confundió en algún momento con otro documento. De todas maneras, hay que comentar que se trata de una reproducción en blanco y negro en la que el artista ha prestado escasa atención al detalle, como si la hubiera realizado con mucha prisa. Por ejemplo, el ancho del camino se halla ocupado por desproporcionadas huellas impresas, la misma desproporción que se observa en algunos glifos, así como en la distribución de algunos de los señores fundadores.

8. La copia de Joseph M. Alexis Aubin. Como en su momento se vio, Aubin compró parte de la colección del padre Pichardo a los herederos de León y Gama, llevándosela consigo a París. ${ }^{53}$ En dicho paquete iban dos copias, la de León y Gama y la de Pichardo, realizando este coleccionista

51 Gondra: Historia..., vol. 3, pág. 1. Las cursivas son mías.

52 Ibídem, págs. 8, 10.

53 Trabulse: Los Manuscritos..., págs. 95-96. 
francés la tercera, que se guarda en Francia. Se trata de una copia en papel de calco, a color, no basada en la de León y Gama como nos dice el Catálogo de Boban, ${ }^{54}$ sino en la de Waldeck (apartado siguiente). Su copia se halla en el Departamento de Manuscritos Orientales de la Biblioteca Nacional de París, bajo la clasificación Mexicain 91 bis. Presenta ligeras señales de haber estado plegada y, aunque su estado de conservación es muy bueno, tiene pequeños daños en puntos muy localizados, donde se ha caído el color. En ella, Aubin llevó a cabo su propio estudio interpretativo, razón por la cual los topónimos suelen estar acompañados de un número que los clasifica, en algunos casos con una glosa interpretativa de su nombre.

No obstante, bajo la denominación de Mexicain 347, existe un cuaderno con anotaciones de Aubin sobre su estudio del documento. En él reproduce nuevamente la Pintura, esta vez a lápiz y por partes, a modo de esquema.

9. La copia de Jean Frederick Waldeck (1766-1875). Waldeck llegó a México en 1825 y al año siguiente trabajó para el entonces llamado Museo de Arqueología, Historia y Etnografía, realizando copias de los monumentos que allí se conservaban, así como de sus manuscritos pictográficos. Entre estas realizó una de la Pintura de la Peregrinación que hoy se conserva en la Colección Ayer de la Newberry Library de Chicago, con la referencia Ayer Art Waldeck, oversize, Box E-1, no. 21.

Se trata de un documento que reproduce de manera muy fidedigna el original. Está realizado a color, sobre papel europeo, y tiene algunas glosas en las que se puede reconocer la mano de Aubin, siendo algunas de ellas las mismas que hay en la copia de éste último. Glass dice que está realizado en base a otra copia sin dar datos más precisos ${ }^{55}$ mientras que ya vimos que Boban cree que está basado en la de León y Gama. Posiblemente, la copia a la que se refiere Glass es a la de Aubin arriba mencionada (número 8) o a la citada por Boban, pero como se pudo comprobar en la Biblioteca Nacional de París, la reproducción de Aubin no estaba basada en la de León y Gama, como hasta ahora se había dicho, sino en la de Waldeck. Y debe ser así y no al contrario, ya que la de Aubin es la que está dibujada sobre el papel de calco. Un asunto que no debe sorprendernos, porque sabemos que Waldeck comenzó a trabajar para el Museo en 1826 y estuvo en México hasta 1837, fecha en la que regresó a París, donde pasó los últimos cuarenta años de su vida. Aubin, por su parte, estuvo en México

54 Boban: Documents pour servir..., vol.II, pág. 247.

55 Glass: Catálogo..., pág. 54. 
por las mismas fechas (1830), estableciendo un contacto que posiblemente se mantuvo en París.

10. La copia de José Fernando Ramírez (1804-1871). Fue publicada por primera vez a color en el Atlas de García Cubas (1858) mientras fue conservador del Museo (figura 5) ${ }^{56}$ Dos cartulinas de estas litografías insertadas en el Atlas son las que están en la Bóveda de Códices de la Biblioteca Nacional de Antropología e Historia, bajo la clasificación 35-14 B y 35-14 C.

Ramírez entregó a García Cubas el dibujo y una carta acompañada de su importante estudio interpretativo, que para aquellos tiempos rompía con todas las líneas interpretativas anteriores, que daban una explicación bíblica del tema. En ese momento el documento comenzó a conocerse también como Códice Ramírez, siendo su copia reproducida en varias ocasiones para comentarios y estudios posteriores. No obstante, presenta algunas deficiencias, como es el reducido tamaño al que queda sometida el área lacustre, con unas consecuencias similares a las que se observaron en la copia del autor desconocido o la de Von Humboldt (figura 4), siendo lo más significativo el hecho de que los personajes queden en diferente distribución con respecto al original y las otras copias que aquí se han visto.

11. La copia de Mateo A. Saldaña de 1908. En la Bóveda de Códices de la Biblioteca Nacional de Antropología de México se halla una foto de la Pintura bajo la clasificación 35-14 d. Se trata de una foto en blanco y negro (0'405 cms. $\times$ 0'284 cms.) que reproduce una nueva copia del documento firmada por Mateo A. Saldaña, a cuya firma se añade "copió del original". ${ }^{57}$ Se alcanza a observar que está elaborada en papel europeo, razón por la que probablemente se trate de aquella que, según testimonio de Salvador Mateos, se conservaba en el Palacio de Bellas Artes de México, hoy en paradero desconocido. ${ }^{58}$

12. La copia de Mateo A. Saldaña de 1933. Es la que se conserva en la Bóveda de Códices de la Biblioteca Nacional de Antropología de México bajo la clasificación 35-14 A. De dimensiones algo más reducidas que el

56 García Cubas: Atlas..., carta 32, Cuadro histórico-geroglífico I.

57 La firma no parece estar sobre el documento mismo sino sobre una tela que se le pegó. Detrás de la foto hay un sello con la dirección de la calle Moneda 13.

58 Mateos Higueras, Salvador: "Colección de estudios sumarios de los códices pictóricos indígenas”, Tlalocan, México, 1944, vol. 1, n. ${ }^{\circ}$ 4, pág. 357. Respecto al Palacio, hay que decir que comenzó a construirse en 1904. En 1933 seguía en construcción y no se inauguró hasta el mes de septiembre de 1934, según los datos del Diccionario de Porrúa, México, 1964, pág. 182. No obstante, este autor la confunde con la de 1933 elaborada en papel de amate.

59 Comunicación personal de Mónica Salazar. 


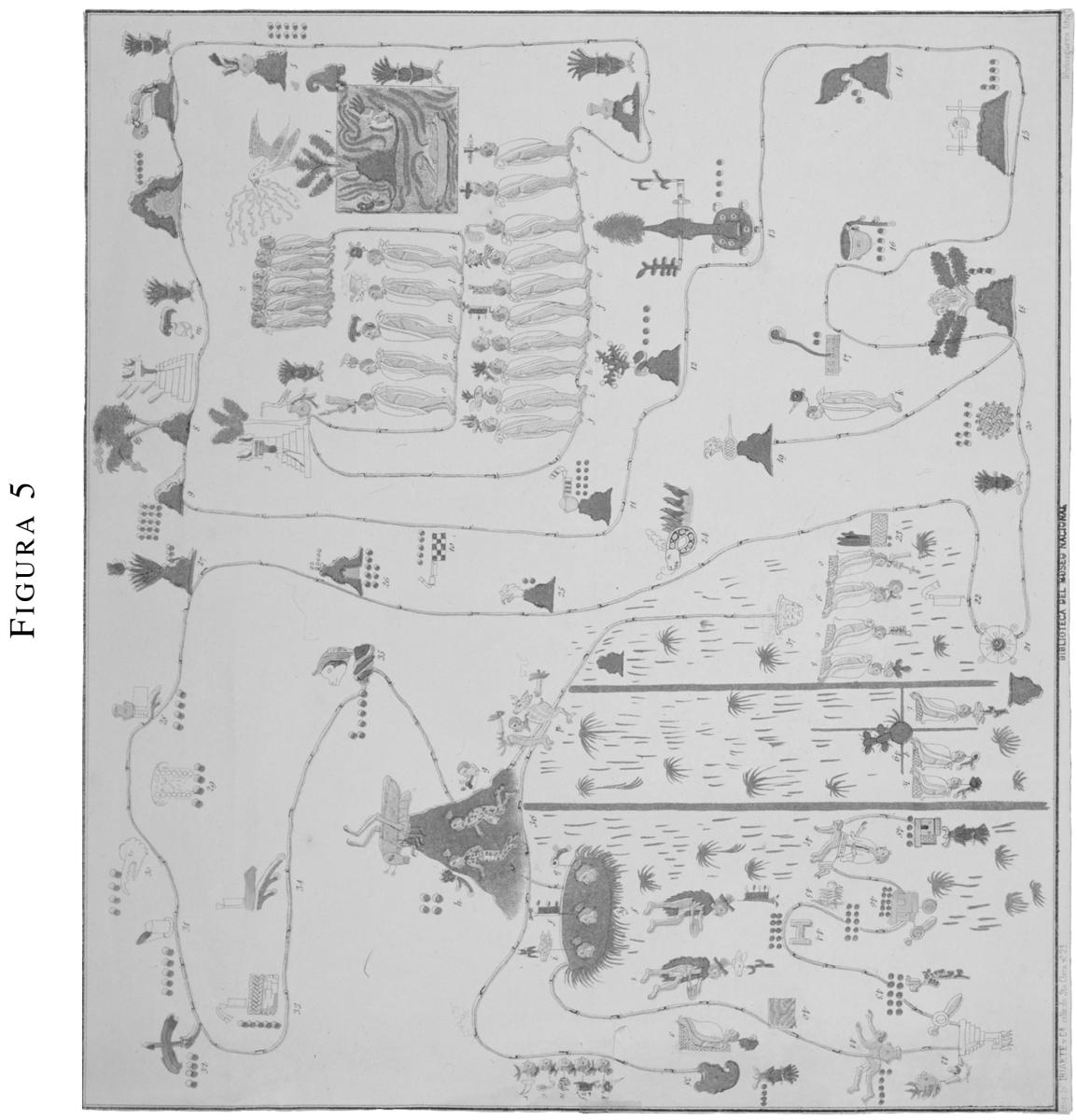


original (0'783 cms. × 0'565 cms.), está realizada a color y sobre papel de amate, hoy día enmarcado, lo cual no nos ha permitido ver el reverso del documento y comprobar si está firmado, ya que Saldaña siempre firmaba sus obras. ${ }^{59}$ Sin embargo, hay muy pocas dudas para afirmar que se trata de una nueva obra de este autor, ya que su similitud con la copia del mismo artista firmada es asombrosa. Reproduce fidedignamente el original, aunque el amate se halla en un estado mucho más deteriorado, llamando la atención los restos de numerosas manchas de color blanco y en sentido vertical, que parecen producto del agua. Es como si el documento hubiera estado mojado y se hubiera secado mientras estaba colgado. ${ }^{60}$

Así pues, un total de doce reproducciones, incluyendo la de Saldaña de 1908 hoy perdida y la clasificada como de autor desconocido, aunque todavía quede por determinarse si se trata de una reproducción inspirada en la del italiano o si más bien se trata de un error que viene de imprenta. Lo que sí se puede asegurar es que en ella se inspiraron Von Humboldt y Clavijero, éste último reproduciendo solo una mínima parte. Copias más fieles, y por ello realizadas directamente del original, son las de León y Gama, Pichardo, Waldeck, Gondra, Ramírez y Saldaña. Por otra parte, sólo recordar que la de Aubin está basada en la de Waldeck y no en la de León y Gama, como hasta ahora se había sostenido.

Respecto a los estudios que hasta hoy día se han realizado de la Pintura, a grandes rasgos puede decirse que los autores anteriores a 1858, como Gemelli, Von Humboldt y Clavijero, dieron una interpretación bíblica del tema con la que rompió Ramírez. A partir de entonces los estudios son prácticamente descriptivos, y no ha sido hasta muy recientemente cuando el manuscrito ha sido objeto de un serio estudio interpretativo. ${ }^{61}$

\section{Consideraciones finales}

El presente trabajo es un claro ejemplo de la suerte que corrieron muchos documentos del México antiguo, como consecuencia de los constantes avatares históricos que vivió aquel país. Pero un hecho interesante y que caracteriza a la Pintura de la Peregrinación de los culhuas-mexitin es el haber formado parte de las mejores colecciones de cada momento.

60 Probablemente, Glass nunca vio esta copia de 1933, razón por la que la confundió con la anterior al decirnos que la clasificada como 35-14 A era de 1908 y estaba realizada en papel europeo.

61 Castañeda de la Paz: "La Pintura...". 
¿Quién no ha oído nunca hablar de la gran biblioteca de Carlos de Sigüenza y Góngora o la que llegó a formar el caballero italiano Lorenzo Boturini?, ¿y de los 16.000 volúmenes que Pichardo llegó a reunir en La Profesa? Cabe entonces preguntarnos dónde están todos esos documentos o qué fue de ellos.

Desafortunadamente, poco sabemos de su suerte. En el pasado sólo algunos interesados le dieron valor a estos manuscritos, siendo ignorados por otros. En este sentido, y como se ha visto, fue una práctica habitual, no sólo en México sino también en Europa, la de apropiarse o comprar objetos antiguos del pasado. Un ejemplo de esta actividad lo tenemos en el mismo director - después conservador- del Museo, José Fernando Ramírez, del que hemos hablado ampliamente. Ramírez no sólo se apropió de la Pintura de la Peregrinación de los Culhuas-mexitin para reproducirla, sino también de otros numerosos documentos, llegando a reunir dos grandes bibliotecas. La primera la vendió en el norte de México, guardándose para sí los documentos más preciados. Con estos y otros que después adquirió — por ejemplo, en La Profesa en el año 1860 - formó una segunda biblioteca, que más tarde vendió en Londres y cuyos restos fueron los que recibieron sus herederos, quienes a su vez la vendieron a Chavero. ${ }^{62}$

Un ejemplo similar fue el que llevó a cabo Aubin al sacar de México un importante volumen de documentos, los cuales desencuadernó y mezcló con otros papeles para que pasaran la aduana mexicana de la manera más inadvertida posible. ${ }^{63}$

Por tanto, a aquéllos que fueron recolectados o adquiridos de las distintas instituciones donde se guardaban y después llevados a otros países, donde se vendieron o entraron a formar parte de nuevas colecciones, hay que añadir los que se destruyeron por el simple abandono, descuido o desidia de las personas que los tenían a su cargo. El destino de los primeros fue muy diverso: algunos se perderían, mientras otros se dispersaron entre diferentes museos, bibliotecas, archivos, o en manos de particulares que posiblemente los conservan todavía hoy.

En 1975, el Handbook of Middle American Indians recogía un total de 434 documentos pictográficos, sin contar las copias que de muchos de ellos se hicieron. Pero si comparamos este volumen con las cifras de aquellos que se lograron reunir en los siglos XVI, XVII y XVIII, donde se incluirían numerosas pictografías, la cantidad es ínfima. No obstante, el mayor

62 Para más información sobre el tema véase Trabulse: Los Manuscritos..., pág. 103.

63 Boban: Documents pour servir..., vol. I, pág. 14. 
acervo de documentos que hoy se posee se haya reunido en la Biblioteca Nacional de Antropología e Historia de la Ciudad de México, que tiene catalogados 115 manuscritos, seguida por la Biblioteca Nacional de París con 78, cuyo grueso está constituido por los documentos que Aubin se llevó de México, legó a Goupil y éste a la Biblioteca donde hoy se conservan.

Si tenemos presente todo lo anterior, y el largo camino que La Pintura de la Peregrinación de los culhuas-mexitin ha recorrido, podemos terminar diciendo que es una verdadera suerte que hoy podamos contar con ella. 